Sains Malaysiana 50(5)(2021): 1243-1254

http://doi.org/10.17576/jsm-2021-5005-05

\title{
Kesignifikan Sistematik Ciri Anatomi Pina dan Stip Angiopteris angustifolia C. Presl dan A. evecta (G. Forst.) Hoffm. [Marattiaceae] di Semenanjung Malaysia
} (Systematic Significance of Anatomical Characteristics of Pinna and Stipe in Angiopteris angustifolia C. Presl and A. evecta (G. Forst.) Hoffm. [Marattiaceae] in Peninsular Malaysia)

\author{
Noraini Talip*, Siti Nor Azah Ayob, Haja Maideen Kader Maideen, Hamidun Bunawan \& Mohamad \\ RUZI ABDUL RAHMAN
}

\begin{abstract}
ABSTRAK
Kajian perbandingan ciri anatomi dan ciri mikromorfologi pina dan stip Angiopteris angustifolia C. Presl dan A. evecta (G. Forst.) Hoffm. [Marattiaceae] di Semenanjung Malaysia telah dijalankan. Sampel kajian diperoleh dari Bangi, Selangor, Bukit Fraser dan Tanah Tinggi Cameron, Pahang. Objektif kajian adalah untuk mengenal pasti dan menyenaraikan ciri anatomi dan mikromorfologi pina yang boleh digunakan untuk pengecaman dan pembezaan dua spesies Angiopteris. Ciri yang ditemui boleh digunakan untuk membina kekunci pengecaman bagi kedua-dua spesies yang dikaji. Anatomi pina dan stip diperhatikan melalui kaedah hirisan dengan mikrotom gelongsor, siatan epidermis dan penjernihan serta cerapan di bawah mikroskop cahaya menggunakan perisian Cell B. Kajian mikromorfologi pula melibatkan teknik saduran emas, titik pengeringan kritikal dan cerapan di bawah mikroskop imbasan elektron menggunakan perisian SmartSEM. Ciri sepunya bagi kedua-dua spesies adalah kehadiran stel ringkas bentuk arka pada stip dan tulang pina, kehadiran sel musilaj yang agak padat pada sel parenkima korteks, peruratan tengah pina dikotom, peruratan tepi pina terbuka dan tidak bercabang dan kehadiran trikom berlengan pada tulang pina. Ciri diagnosis yang ditemui ialah peruratan palsu pada pina $\mathrm{A}$. angustifolia, bentuk luaran permukaan abaksial stip $\mathrm{A}$. angustifolia berbentuk bulatan lebar manakala A. evecta berbentuk $3 / 4$ bulatan. Hiasan kutikel pada epidermis abaksial pina A. angustifolia dengan dinding periklin tenggelam dan dinding antiklin timbul sebaliknya pada A. evecta dinding periklin timbul dan dinding antiklin tenggelam. Kesimpulannya, ciri anatomi dan mikromorfologi pina dan stip mempunyai nilai taksonomi yang boleh digunakan bagi pengecaman dan pembezaan kedua-dua spesies Angiopteris yang dikaji.
\end{abstract}

Kata kunci: Anatomi; Angiopteris angustifolia; Angiopteris evecta; Marattiaceae; pina

\section{ABSTRACT}

A comparative study on the pinna and stipe anatomical and micromorphological characters of Angiopteris angustifolia C. Presl and A. evecta (G. Forst.) Hoffm. [Marattiaceae] in Peninsular Malaysia has been conducted. Fresh samples were collected from Bangi, Selangor, Fraser Hill and Cameron Highland, Pahang. The objectives of the study were to determine and to identify the pinna anatomical and micromorphological characteristics that could be useful to differentiate two Angiopteris species. These characters could be used to construct a dichotomy key for the identification of the species. The anatomy of pinna and stipe were observed through sectioning of sliding microtome, pinna leaf clearing and pinna epidermis mechanical scrapping, and observation under light microscope using Cell B software. For micromorphological study, the techniques involved were gold coating, critical point drying and observation under electron scanning microscope using SmartSEM software. General characteristics in both species were presence of simple stele with arch-shaped in the stipe and midribs, presence of mucilage cells which was relatively dense in the cortical parenchyma cells, dichotomous areolar venation in pinna, an open and unbranched marginal venation system and the presence of branched trichomes in the midribs. The diagnostic characteristics found were pinna false vein in A. angustifolia, a wide circular shape of abaxial stipe surface of A. angustifolia whereas $3 / 4$ circular in A. evecta. The cuticle ornamentation on abaxial epidermal pinna in A. angustifolia showed sunken periclinal wall, and raised anticlinal wall, whilst raised periclinal wall and sunken anticlinal wall in A. evecta. As a conclusion, the anatomical and micromorphological characteristics of pinna and stipe have taxonomic value which can be used to identify and to differentiate both Angiopteris species studied.

Keywords: Anatomy; Angiopteris angustifolia; Angiopteris evecta; Marattiaceae; pinna 


\section{Pengenalan}

Merujuk kepada Bidin (1984), PPG I (2016) dan Latiff (2015), pteridophyta dibahagikan kepada dua kelas iaitu Lycopodiopsida (lycophytes) dan Polypodiopsida (paku pakis). Polypodiopsida pula terbahagi kepada empat subkelas iaitu Equisetidae, Ophioglossidae, Marattiidae dan Polypodiidae. Marattiidae terdiri daripada satu order dan satu famili sahaja iaitu Marattiales dan Marattiaceae (PPG I 2016). Menurut Holttum (1968), Marattiaceae mempunyai tujuh genus, manakala Smith et al. (2006) menyatakan terdapat empat genus. PPG I (2016) dan Christenhusz et al. (2011) merekodkan enam genus di dalam famili ini iaitu; Angiopteris Hoffm., Christensenia Maxon, Danaea Sm., Eupodium J.Sm., Marattia Sw. dan Ptisana Murdock. Bilangan spesies Marattiaceae sering berubah mengikut sistem pengelasan yang berbeza. He dan Christenhusz (2013) menyatakan Marattiaceae mempunyai 100 spesies sementara PPG I (2016) menganggarkan 111, Christenhusz et al. (2017) pula menyatakan terdapat 135 spesies dalam famili ini.

Marattiaceae merupakan paku pakis purba yang mana fosilnya telah ditemui sejak zaman Paleozoik (Carboniferous) iaitu 360 juta tahun lalu (Hill \& Camus 1986; Holttum 1968). Marattiaceae juga dikenali sebagai paku pakis gergasi (Christenhusz et al. 2017) dan hanya tiga genus daripada famili ini terdapat di Semenanjung Malaysia iaitu Angiopteris (Holttum 1968; Noraini et al. 2008), Christensenia (Holttum 1968) dan juga Marattia (Maideen et al. 2002). Menurut Blomquist (1922), Marattiaceae merupakan famili paku pakis yang mempunyai ciri anatomi yang amat kompleks dan kebanyakan kajian anatomi bagi Marattiaceae juga tidak lengkap. Sehingga kini hanya dua spesies Angiopteris yang direkodkan terdapat di Semenanjung Malaysia iaitu A. angustifolia dan A. evecta (Holttum 1968; Noraini et al. 2008).

Angiopteris merupakan paku pakis yang unik kerana pokoknya bersaiz amat besar berbanding genus lain serta mempunyai spora berbentuk trilet yang terkandung dalam sporangium. Sporangiumnya pula bercantum di antara satu sama lain dan dikenali sebagai sinangium. Angiopteris juga dikenali dengan nama tempatan paku gajah. Bukti fosil yang ditemui menunjukkan ia merupakan tumbuhan primitif (Holttum 1968; van Konijnenburg-van Cittert 1975). Jumlah spesies bagi genus ini adalah berbeza-beza. Merujuk kepada Hill dan Camus (1986) dan Murdock (2008), Angiopteris mempunyai sebanyak 10-30 spesies sementara He dan Christenhusz (2013) menyatakan bilangan spesies Angiopteris adalah 30-40. PPG I (2016) dan Christenhusz et al. (2017) pula merekodkan genus ini sebanyak 30 spesies.
Marattiaceae mempunyai taburan di kawasan tropika (Murdock 2008) dan juga di kawasan iklim sederhana atau temperat (Hill \& Camus 1986; Holttum 1968). Ia merupakan paku-pakis daratan dan bersaiz besar (Murdock 2008). Ia mempunyai rizom yang besar sama ada menegak atau menjalar, xilem poliarka, trikom akar mempunyai septat, manakala akar, batang dan daun mempunyai salur musilaj (Smith et al. 2006). Daunnya bersaiz besar dan biasanya mempunyai 1-4 pina, pangkal daun membengkak dikenali sebagai pulvinus. Sporangiumnya dikenali sebagai sinangium dan terdapat di bahagian hujung pada abaksial daun sementara sporanya berbentuk monolet atau trilet (Murdock 2008; Smith et al. 2006). Morfologi kedua spesies kajian boleh dirujuk pada Rajah 1 .

Angiopteris mempunyai taburan yang meluas di kawasan Paleotropika iaitu dari Madagascar ke Kepulauan Pasifik Selatan. Genus ini dibawa masuk ke Hawaii, Jamaica dan Amerika Tengah sehingga menjadi invasif di kawasan tersebut (Murdock 2008). Angiopteris evecta mempunyai nilai ekonomi dan perubatan tradisi yang mana akarnya boleh digunakan untuk rawatan rambut (Mustaricuhie et al. 2016) dan rawatan menghentikan pendarahan kerana keguguran (Noraini et al. 2008).

Fronnya pula digunakan untuk rawatan ulser, sakit perut, sakit badan, batuk dan rawatan rambut (Mustarichie et al. 2016). Rizomnya pula dipercayai boleh digunakan untuk rawatan patah tulang dan digunakan sebagai pewangi dengan campuran minyak kelapa (Sathiyaraj et al. 2015). Krozier boleh dijadikan ulam (de Winter \& Amoroso 2003) dan sporanya untuk merawat kusta dan penyakit kulit (Bidin 1985). Spesies ini juga sesuai sebagai tanaman hiasan kerana fronnya yang unik. A. angustifolia pula dikatakan mempunyai aktiviti sitotoksik yang mungkin berpotensi merawat kanser dan sesuai sebagai tanaman hiasan (Sitorus 2013).

Blomquist (1922) menjalankan kajian perubahan struktur vaskular $A$. evecta mengikut peringkat perkembangan sporofit. Hill dan Camus (1986) telah membuat kajian mengenai saiz stoma bagi Angiopteris juga direkodkan dalam kajian ini iaitu $30-76 \times 28-44$ $\mu \mathrm{m}$. Seterusnya Rolleri et al. (1991) telah menjalankan kajian mengenai ciri epidermis pina Angiopteris, Danea dan Marattia. Kajian mendapati saiz stoma pada pina $A$. angustifolia lebih kecil daripada $A$. evecta; (A. angustifolia $(46 \times 28)$, A. evecta $(84 \times 32))$. Selain itu, terdapat satu atau dua bilangan cincin sel subsidiari pada $A$. angustifolia manakala $A$. evecta mempunyai satu sahaja. Stoma bagi A. angustifolia adalah siklositik manakala pada $A$. evecta adalah siklositik, tetrasitik, staurositik dan anisositik. Jenis trikom $A$. angustifolia pula adalah jenis sisik 


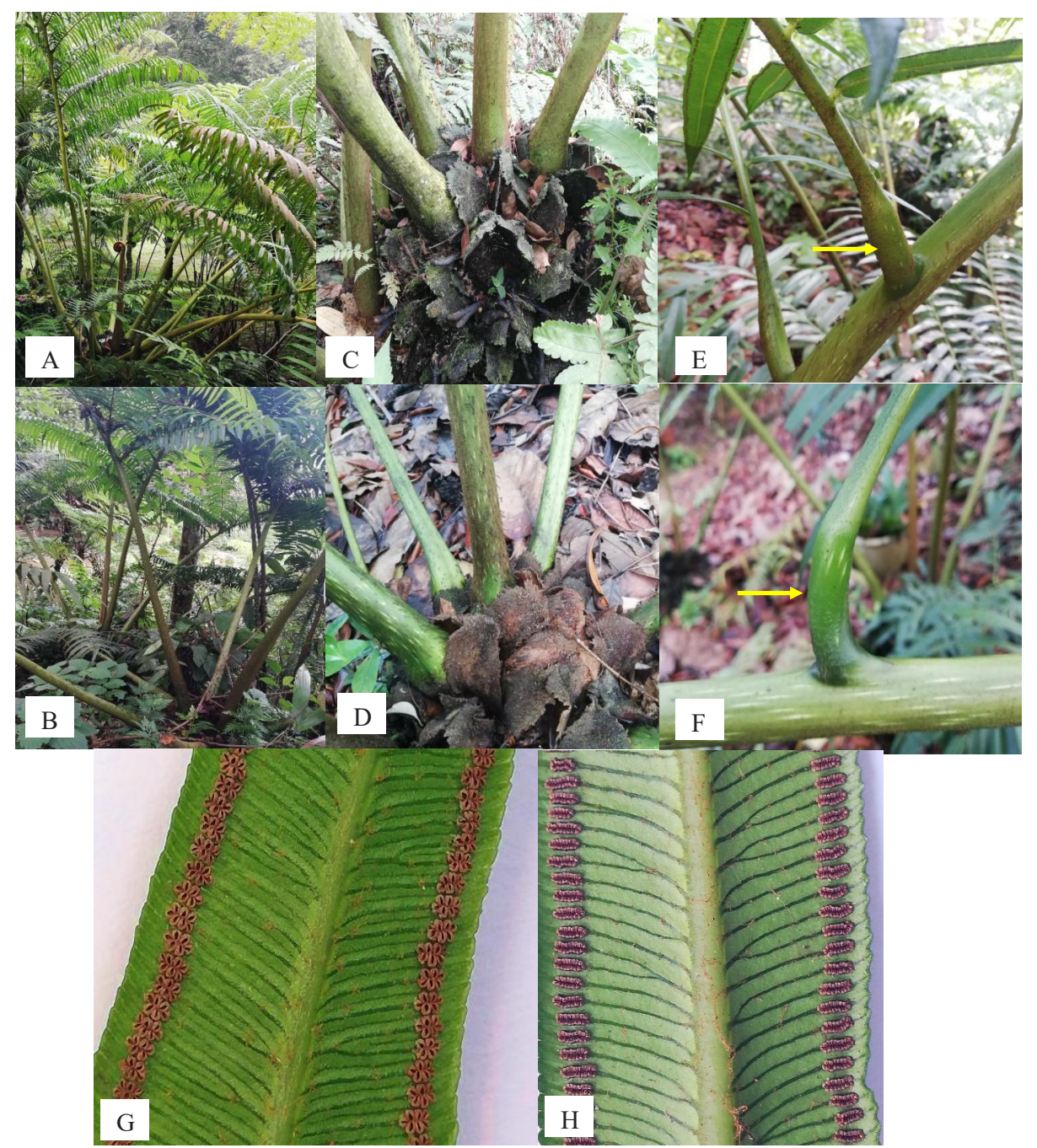

RAJAH 1. Ciri morfologi Angiopteris angustifolia dan A. evecta.: $(\mathrm{a}-\mathrm{b})$ habitat dan fron, (c - d) rizom yang besar, (e - f) pulvinus pada pangkal petiol dan bintil lentisel (anak panah), dan $(\mathrm{g}-\mathrm{h})$ sporangium di bahagian tepi pada permukaan abaksial epidermis pina dan peruratan palsu

sementara $A$. evecta berlengan. Anatomi $A$. evecta turut mempunyai corak peruratan dikotom dan terbuka. Pina mempunyai ciri hipostomatik iaitu stoma hanya hadir pada permukaan abaksial sahaja. Stoma biasanya ampisiklik dan mempunyai empat hingga enam sel subsidiari. Kedua-dua epidermis adaksial dan abaksial mempunyai dinding antiklin sinuos dan tersusun secara tidak sekata (Srivastava 2008).

Kajian ciri morfologi paku pakis terpilih pula telah dijalankan oleh Rosalin (2014). Walau bagaimanapun, ciri-ciri morfologi fron, pina dan sporangium $A$. evecta yang dihuraikan dalam kajian tersebut merupakan ciri morfologi yang sebenarnya terdapat pada $A$. angustifolia di Semenanjung Malaysia. Hal ini merupakan salah satu contoh yang mana spesies daripada genus Angiopteris sering disalah anggap sebagai $A$. evecta.

Menurut Holttum (1968), kesemua spesies dalam genus ini mempunyai ciri umum yang sangat serupa. Holttum (1968), Hill dan Camus (1986) dan juga Srivastava (2008) menyatakan terdapat ahli taksonomi yang meletakkan kesemua spesies dalam genus ini sebagai $A$. evecta. Kesukaran pengecaman bagi kedua- 
dua spesies ini disebabkan oleh morfologinya yang hampir sama dan perbezaan bagi keduanya memerlukan kajian komprehensif. Sehingga kini, kajian anatomi dan mikromorfologi daun yang komprehensif bagi kedua-dua spesies ini masih lagi dangkal. Kajian perbandingan ciri anatomi dan mikromorfologi daun boleh digunakan bagi membantu dalam proses pengelasan dan pengecaman pada peringkat spesies dan genus (Metcalfe \& Chalk 1983; Noraini et al. 2019). Senarai lengkap ciri anatomi dan mikromorfologi yang diperoleh tersebut dapat digunakan untuk menyelesaikan masalah perbezaan dan pengecaman kedua-dua spesies $A$. angustifolia dan $A$. evecta. Kajian perbandingan ciri anatomi dan mikromorfologi pina ini dijalankan bagi melihat kesignifikanan ciri anatomi dan mikromorfologi pina kedua-dua spesies dan membina kekunci pengecaman spesies $A$. angustifolia dan $A$. evecta dengan menggunakan ciri anatomi dan mikromorfologi yang diperoleh.

\section{BAHAN DAN KAEDAH}

Kajian dijalankan ke atas enam sampel yang terdiri daripada tiga sampel $A$. angustifolia dan tiga sampel $A$. evecta. Senarai sampel kajian boleh dirujuk pada Jadual 1. Spesimen ditetapkan pada larutan AA pada nisbah 3:1 (70\% alkohol: 30\% asid asetik). Kaedah yang digunakan dalam kajian anatomi ialah kaedah hirisan dengan mikrotom gelongsor, siatan epidermis dan penjernihan serta cerapan di bawah mikroskop cahaya menggunakan perisian Cell B. Keratan dilakukan pada bahagian lamina, tulang daun dan petiol dan diwarnakan dengan Safranin dan Alcian Green. Kajian mikromorfologi pula melibatkan teknik saduran emas, titik pengeringan kritikal dan cerapan di bawah mikroskop imbasan elektron menggunakan perisian SmartSEM. Kaedah kajian anatomi adalah mengikut kaedah Johansen (1940) dan Sass (1958) yang diubah suai pada bahan medium sokongan untuk keratan spesimen daripada karot ditukar kepada polisterin. Kajian dan huraian ciri mikromorfologi pula adalah mengikut Barthlott (1990) dan Barthlott et al. (1998).

JADUAL 1. Senarai dan maklumat spesies kajian

\begin{tabular}{|c|c|c|c|}
\hline Nama spesies & $\begin{array}{c}\text { Kod } \\
\text { spesimen }\end{array}$ & $\begin{array}{l}\text { Tarikh kutipan dan } \\
\text { nama pengumpul }\end{array}$ & Lokaliti \\
\hline \multirow[t]{3}{*}{ A. evecta } & AE-1 & $\begin{array}{l}8 \text { Julai 2019; Siti Nor Azah Ayob dan } \\
\text { Mohamad Ruzi Abdul Rahman }\end{array}$ & $\begin{array}{l}\text { Taman Paku Pakis, } \\
\text { UKM Bangi, Selangor }\end{array}$ \\
\hline & AE-2 & $\begin{array}{l}9 \text { September 2019; Siti Nor Azah } \\
\text { Ayob dan Mohamad Ruzi Abdul } \\
\text { Rahman }\end{array}$ & $\begin{array}{c}\text { Parit Fall, } \\
\text { Tanah Tinggi Cameron, Pahang }\end{array}$ \\
\hline & AE-3 & $\begin{array}{l}20 \text { Julai 2019; Siti Nor Azah Ayob } \\
\text { dan Mohamad Ruzi Abdul Rahman }\end{array}$ & Trail Bishop, Bukit Fraser \\
\hline \multirow[t]{3}{*}{ A. angustifolia } & AA-1 & $\begin{array}{l}8 \text { Julai 2019; Siti Nor Azah Ayob dan } \\
\text { Mohamad Ruzi Abdul Rahman }\end{array}$ & $\begin{array}{l}\text { Taman Paku Pakis, } \\
\text { UKM Bangi, Selangor }\end{array}$ \\
\hline & AA-2 & $\begin{array}{l}20 \text { Julai 2019; Siti Nor Azah Ayob } \\
\text { dan Mohamad Ruzi Abdul Rahman }\end{array}$ & $\begin{array}{c}\text { Parit Fall, } \\
\text { Tanah Tinggi Cameron, Pahang }\end{array}$ \\
\hline & AA-3 & $\begin{array}{l}20 \text { Julai 2019; Siti Nor Azah Ayob } \\
\text { dan Mohamad Ruzi Abdul Rahman }\end{array}$ & $\begin{array}{c}\text { Habu, } \\
\text { Tanah Tinggi Cameron, Pahang }\end{array}$ \\
\hline
\end{tabular}

\section{HASIL KAJIAN}

Hasil kajian menunjukkan terdapat sepuluh ciri umum anatomi dan mikromorfologi pina bagi kedua-dua spesies Angiopteris. Ciri umum ini merupakan ciri sepunya yang dikongsi bersama dalam genus Angiopteris. Hasil pemerhatian di bawah mikroskop cahaya menunjukkan kedua-dua spesies kajian mempunyai corak dinding antiklin epidermis adaksial melengkung kepada berombak (Rajah 2(e) - 2(f)). Kehadiran lilin yang berfungsi sebagai lapisan pelindung pada permukaan epidermis 
daun merupakan salah satu ciri mikromorfologi yang mempunyai nilai taksonomi yang tinggi dalam kajian sistematik tumbuhan (Barthlott et al. 1998; Mohd. Norfaizal 2019; Noraini \& Cutler 2009). Cerapan di bawah mikroskop imbasan elektron pada permukaan epidermis adaksial dan abaksial mendapati kedua-dua spesies kajian mempunyai corak ukiran kutikel yang jelas serta kehadiran lapisan lilin filem dan bintil (Rajah 2(a) - 2(d)). Jenis lilin filem merujuk kepada lapisan lilin yang rata dan agak licin manakala jenis lilin bintil bermaksud berbutir, berbiji atau bergranul. Jenis lilin ini merupakan ciri sepunya yang dapat menyokong pengelasan genus Angiopteris (Maratteaceae).

Huraian ciri anatomi dan mikromorfologi pina dalam kajian ini menunjukkan $A$. angustifolia dan $A$. evecta mempunyai stoma jenis hipostomatik iaitu hadir pada permukaan epidermis abaksial sahaja (Rajah 2(b) dan Rajah 2(f)). Hasil kajian ini menyokong kajian yang dibuat oleh Rolleri et al. (1991) dan Srivastava (2008). Cerapan ke atas struktur stoma di bawah mikroskop imbasan elektron mendapati kedua-dua spesies kajian mempunyai taburan stoma secara rawak. Kedua-dua spesies mempunyai bentuk pasangan sel pengawal elips, struktur bingkai dan birai stoma yang jelas dan timbul. Stoma superfisial dengan sel subsidiari jelas dan tidak merangkum stoma (Rajah 2(b) dan Rajah 2(c)).

Pemerhatian di bawah mikroskop imbasan elektron ke atas kedua-dua spesies mendapati trikom hadir pada epidermis abaksial pina. Hasil pemerhatian di bawah mikroskop cahaya pula menunjukkan trikom berlengan hadir pada permukaan epidermis abaksial tulang pina A. angustifolia dan $A$. evecta (Rajah 2(d)). Hasil kajian mendapati sel epidermis tulang pina $A$. angustifolia dan $A$. evecta terdiri daripada satu lapisan sel dengan setiap sel mempunyai nisbah tinggi kepada lebar 1:1-1:2. Keduadua spesies kajian ini juga mempunyai bilangan lapisan sel kolenkima yang sama pada stip dan juga pada tulang pina. Pada bahagian stip, bilangan lapisan sel kolenkima adalah sebanyak 3 - 5 lapisan di bawah lapisan epidermis. Pada bahagian tulang pina pula terdapat 2 - 3 lapisan sel kolenkima di bawah permukaan epidermis adaksial dan abaksial. Kehadiran sel kolenkima (sel hipodermis) turut dicerap di bawah lapisan sel epidermis adaksial pada pina. Hasil kajian turut merekodkan kehadiran sel klorenkima di bawah lapisan sel kolenkima adaksial pada tulang pina dan pina kedua-dua spesies kajian.
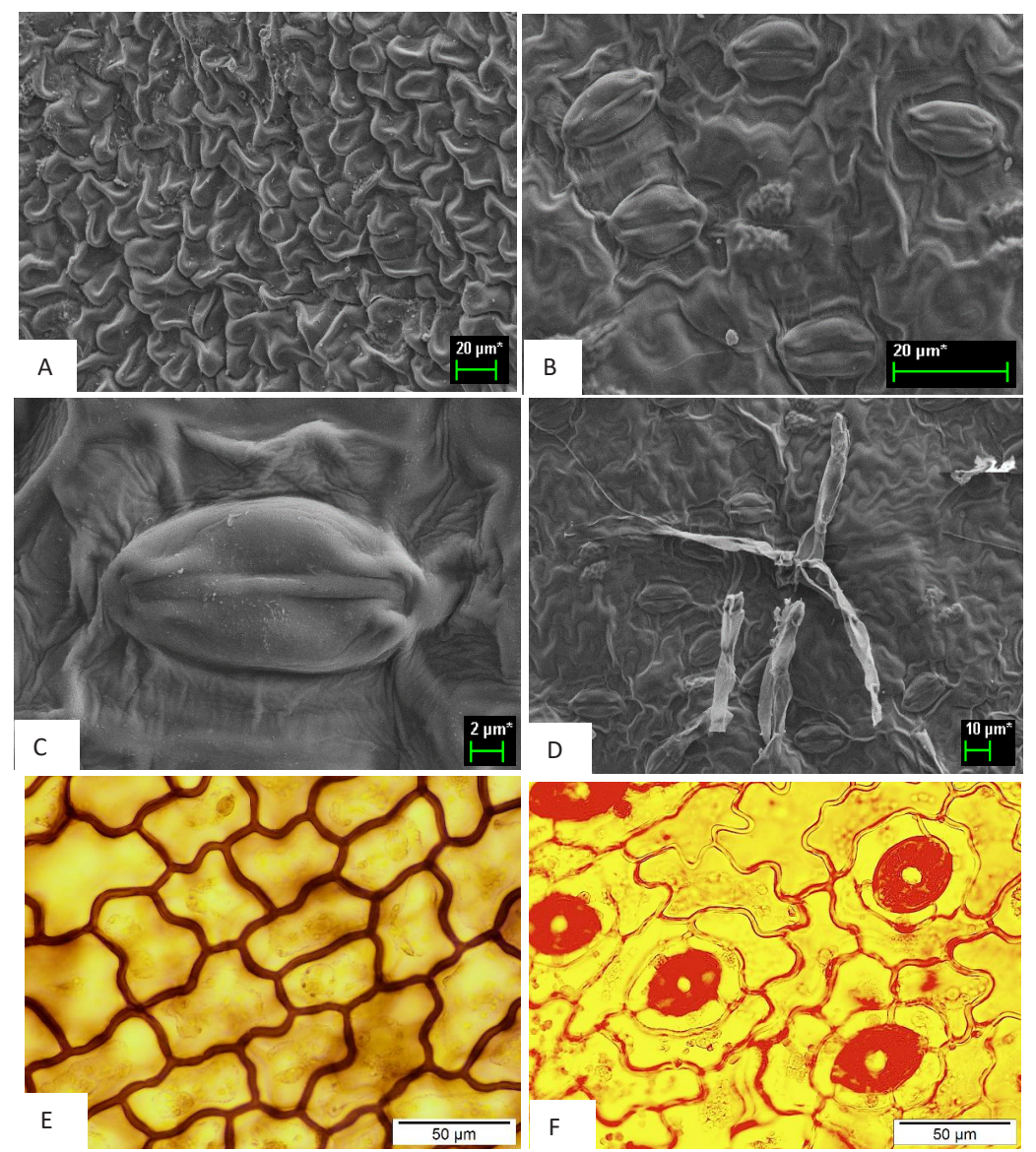

RAJAH 2. Ciri mikromorfologi epidermis pina Angiopteris angustifolia: (a) Lapisan filem dan bintil pada permukaan epidermis adaksial dan hiasan kutikel pada permukaan epidermis adaksial, (b) Lapisan filem dan bintil pada permukaan epidermis abaksial dan hiasan kutikel pada permukaan epidermis abaksial, (c) Stoma superfisial pada permukaan epidermis abaksial, dan (d) Trikom lengan-3 pada permukaan epidermis abaksial. Ciri anatomi epidermis pina Angiopteris evecta: (e) Corak dinding antiklin permukaan epidermis adaksial, dan (f) Corak dinding antiklin permukaan epidermis abaksial, stoma anisositik, tetrasitik dan siklositik 
Corak peruratan daun pada paku-pakis adalah penting dan telah digunakan bagi pengelasan spesies, genus dan famili (Maideen et al. 2013; Noraini et al. 2012; Wagner 1979). Holtthum (1965) dan Srivastava
(2008) menyatakan $A$. evecta mempunyai peruratan pina jenis dikotom. Hasil kajian menyokong kenyataan yang A. evecta dan A. angustifolia mempunyai corak peruratan tengah dikotom serta peruratan tepi terbuka dan tidak bercabang (Rajah 3(a) - 3(e)).
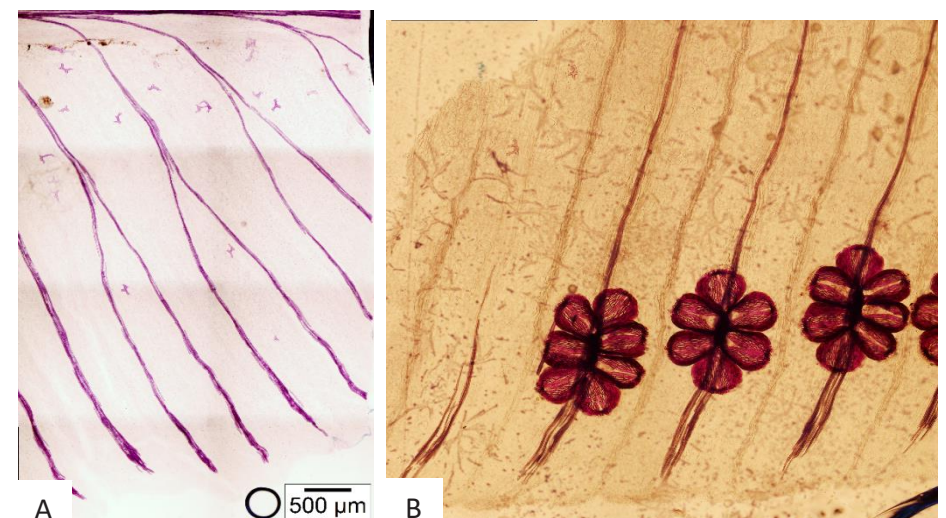

A
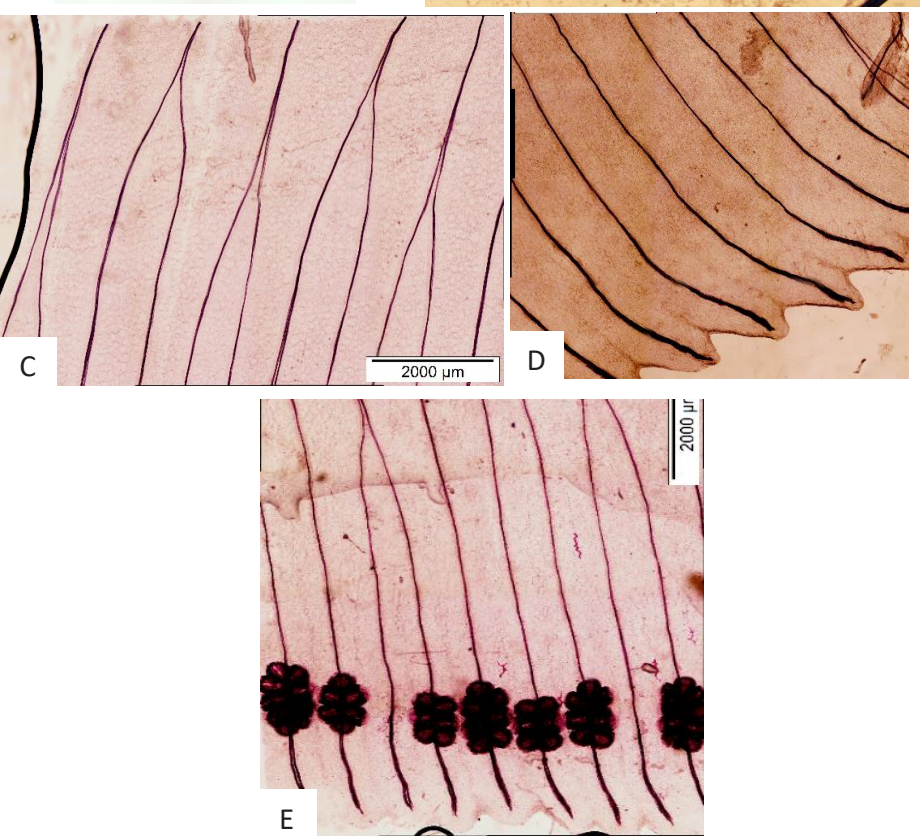

RAJAH 3. Ciri anatomi peruratan pina Angiopteris angustifolia: (a) Peruratan tengah pina dikotom, peruratan tepi pina jenis tidak lengkap, hujung bebas dan tidak bercabang, tidak menyentuh tepi pina dan (b) Peruratan palsu jelas pada pina fertil. Ciri anatomi peruratan pina Angiopteris evecta: (c) Peruratan tengah pina jenis dikotom, (d) Peruratan tepi pina jenis tidak lengkap, hujung bebas dan tidak bercabang, menyentuh tepi pina, dan (e) Peruratan palsu tidak jelas pada pina fertil
Menurut Ogura (1972), stel adalah organ pengangkutan atau sistem vaskular bagi pteridofit. Beliau juga telah mengenal pasti sepuluh bentuk utama stel pada paku-pakis. Noraini et al. (2015) dan Ogura (1972) turut membahagikan bentuk stel kepada stel ringkas dan stel kompleks yang mana stel ringkas merujuk kepada kehadiran satu berkas vaskular sahaja manakala stel kompleks merujuk kepada kehadiran lebih daripada satu 
berkas vaskular. Hasil kajian ini merekodkan stel pada petiol, stip dan tulang pina kedua-dua spesies Angiopteris yang dikaji merupakan stel ringkas, berbentuk arka dengan hujung stel melengkung ke dalam (Rajah 4(b)). Hasil kajian ini membuktikan bahawa ciri anatomi berkas vaskular boleh digunakan untuk pengecaman genus kajian.

Sel musilaj merupakan sel perembes yang penting pada paku pakis sebagai salah satu sistem pertahanan mekanik dan menyokong tumbuhan daripada kehilangan air bagi memastikan tumbuhan kekal hidrat (Noraini et al. 2019). Kehadiran salur musilaj pada akar, batang dan daun juga merupakan ciri utama bagi famili Marattiaceae (Murdock 2008; Ogura 1972; Smith et al. 2006). Sel musilaj yang hadir secara agak padat pada sel parenkima korteks terutama kawasan berdekatan stel pada petiol (Rajah 4(e)), stip dan tulang pina.
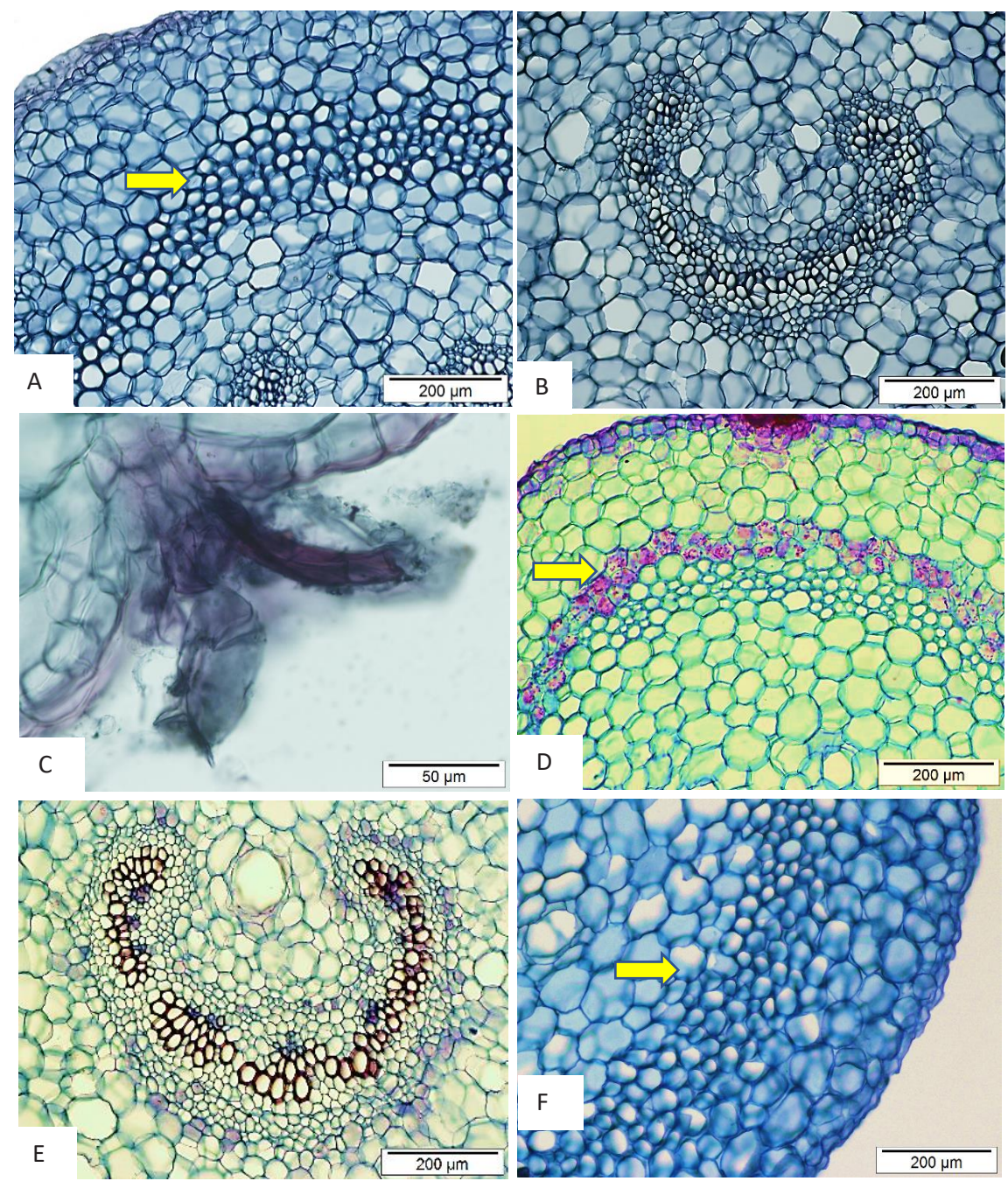

RAJAH 4. Ciri anatomi petiol Angiopteris angustifolia: (a) Lapisan parenkima menebal (anak panah), (b) Stel, dan (c) Trikom ringkas multisel. Ciri anatomi petiol Angiopteris evecta: (d) Bintil kanji (anak panah), (e) Stel dan (f) Lapisan parenkima menebal (anak panah)

Hasil kajian menunjukkan bentuk luaran stip $A$. angustifolia dan $A$. evecta merupakan ciri umum yang mana kedua-duanya mempunyai permukaan adaksial cembung serta terdapat lekuk di kiri dan kanan kawasan penyambungan permukaan adaksial dan permukaan abaksial (Jadual 2). Bagi bentuk luaran tulang pina pula, 
hasil kajian menunjukkan kedua-dua spesies kajian ini mempunyai permukaan adaksial cembung berbonggol dan permukaan abaksial berbentuk arka. Selain daripada bentuk luaran stip dan tulang pina, bentuk luaran tepi pina juga menunjukkan persamaan antara kedua-dua spesies kajian iaitu bentuk luaran tepi pina menirus dengan saiz mengecil menuju hujung tepi pina dan melengkung $90^{\circ}$ ke arah permukaan epidermis abaksial (Jadual 3). Bentuk luaran stip dan tulang pina sering digunakan dalam kajian sistematik tumbuhan namun bentuk luaran tepi pina agak jarang digunakan. Kajian ini membuktikan ketiga-tiga ciri ini adalah signifikan dan mempunyai nilai taksonomi yang tinggi pada peringkat genus.

JADUAL 2. Bentuk luaran stip A. angustifolia dan A. evecta berserta huraian dan ilustrasi

\begin{tabular}{ccc}
\hline Bentuk & Huraian bentuk & Adaksial: cembung \\
Bentuk 1 & $\begin{array}{c}\text { Abaksial: permukaan berbentuk bulatan lebar, } \\
\text { terdapat lekuk di kiri dan kanan kawasan pe- } \\
\text { nyambungan adaksial dan permukaan abaksial } \\
\text { Adaksial: cembung } \\
\text { Bentuk 2 }\end{array}$ & $\begin{array}{c}\text { A. angustifolia } \\
\text { dapat lekuk di kiri dan kanan kawasan penyam- } \\
\text { bungan adaksial dan permukaan abaksial }\end{array}$ \\
\hline
\end{tabular}

JADUAL 3. Bentuk luaran tepi pina A. angustifolia dan A. evecta beserta huraian dan ilustrasi

\begin{tabular}{ccc}
\hline Bentuk & Huraian bentuk & Ilustrasi dan spesies \\
\hline Bentuk 1 & $\begin{array}{c}\text { Menirus-hujung tumpul, saiz mengecil menuju } \\
\text { hujung tepi pina, melengkung } 90^{\circ} \text { ke arah epi- } \\
\text { dermis abaksial }\end{array}$ & A. angustifolia \\
Bentuk 2 & $\begin{array}{c}\text { Menirus-hujung membulat, saiz mengecil menu- } \\
\text { ju hujung tepi pina, melengkung } 90^{\circ} \text { ke arah } \\
\text { epidermis abaksial }\end{array}$ & A. evecta \\
\hline
\end{tabular}

Pemerhatian di bawah mikroskop imbasan elektron menunjukkan hiasan kutikel pada permukaan epidermis adaksial dan abaksial $A$. angustifolia mempunyai Corak 1 dan Corak 3 manakala $A$. evecta mempunyai Corak 2 dan Corak 4 (Jadual 4). Corak hiasan kutikel jelas membezakan dua spesies kajian. Hasil pemerhatian corak dinding antiklin epidermis abaksial di bawah mikroskop cahaya bagi $A$. angustifolia menunjukkan ia mempunyai dinding antiklin lurus, melengkung kepada berombak manakala $A$. evecta pula mempunyai dinding antiklin lurus, melengkung kepada berombak dan berombak kepada sinuat. Bentuk sinuat pada epidermis abaksial $A$. evecta turut ditemui dalam kajian Rolleri et al. (1991) dan Srivastava (2008), yang mana terdapat pada $A$. angustifolia. 
JADUAL 4. Corak hiasan kutikel pada permukaan epidermis adaksial dan abaksial A. angustifolia dan A. evecta

\begin{tabular}{|c|c|}
\hline Corak & Huraian corak hiasan kutikel \\
\hline Corak 1 & $\begin{array}{l}\text { Dinding periklin tenggelam membentuk lopak yang lebar, dinding antiklin timbul memben- } \\
\text { tuk rabung nipis pada epidermis adaksial }\end{array}$ \\
\hline Corak 2 & $\begin{array}{l}\text { Dinding antiklin tenggelam, dinding periklin timbul membentuk bonjolan kubah pada epi- } \\
\text { dermis adaksial }\end{array}$ \\
\hline Corak 3 & $\begin{array}{l}\text { Dinding periklin tenggelam membentuk lopak yang lebar, dinding antiklin timbul memben- } \\
\text { tuk rabung pada epidermis abaksial }\end{array}$ \\
\hline Corak 4 & Dinding periklin timbul, dinding antiklin tenggelam sedikit pada epidermis abaksial \\
\hline
\end{tabular}

\section{PERBINCANGAN}

Hasil kajian menunjukkan terdapat tujuh perbezaan utama ciri anatomi dan mikromorfologi pina bagi keduadua spesies Angiopteris yang merupakan ciri diagnostik yang boleh digunakan untuk pembezaan spesies. Holttum (1968) menyatakan terdapat peruratan palsu antara peruratan sebenar pada $A$. angustifolia bermula dari bahagian tepi hingga tengah pina manakala peruratan palsu tidak hadir pada $A$. evecta. Hasil kajian membuktikan peruratan palsu tersebut hadir pada peruratan pina $A$. angustifolia tetapi tidak hadir pada peruratan pina $A$. evecta. Peruratan tepi pina $A$. angustifolia tidak menyentuh bahagian tepi pina tetapi pada $A$. evecta peruratan tepi menyentuh sehingga ke tepi pina. Ciri peruratan pina ini merupakan ciri utama dan unik dalam perbandingan keduadua spesies $A$. angustifolia dan $A$. evecta.

Bagi bentuk luaran stip, $A$. angustifolia mempunyai Bentuk 1 manakala Bentuk 2 diperhatikan pada $A$. evecta (Jadual 2). Ciri bentuk luaran stip ini juga sangat sesuai untuk membezakan kedua spesies ini kerana ciri ini kurang dipengaruhi faktor persekitaran (Maideen et al. 2018, 2013; Noraini et al. 2012; Ogura 1972). Hasil kajian merekodkan bentuk luaran tepi pina $A$. angustifolia adalah seperti Bentuk 1 sementara $A$. evecta mempunyai Bentuk 2 (Jadual 3). Perbezaan bentuk luaran ini membuktikan nilai taksonomi pada ciri anatomi tersebut yang boleh digunakan bagi perbandingan dan pengecaman spesies seperti Angiopteris.
Hasil kajian menunjukkan A. angustifolia mempunyai stoma tetrasitik dan staurositik manakala $A$. evecta mempunyai stoma anisositik, tetrasitik dan staurositik. Stoma anisositik ialah stoma yang dikelilingi oleh tiga sel subsidiari, stoma tetrasitik pula adalah struktur stoma yang dikelilingi oleh empat sel subsidiari manakala stoma staurositik ialah stoma yang dikelilingi oleh 5-10 sel subsidiari (Noraini et al. 2019). Indeks stoma menunjukkan A. evecta mempunyai kepadatan stoma yang lebih tinggi iaitu $15 \%$ berbanding $A$. angustifolia iaitu 13\%. Perbezaan jenis stoma dan bilangan sel subsidiari ini menyokong kenyataan oleh Noraini et al. (2019) bahawa stoma dan sel subsidiari merupakan ciri penting dalam perbandingan dan pengecaman spesies dan genus tumbuhan.

Pemerhatian di bawah mikroskop imbasan elektron mendapati A. angustifolia mempunyai trikom berlengan-3 pada peruratan pina epidermis abaksial sahaja. Pada A. evecta pula kehadiran trikom berlengan-3 dengan dinding beralur hadir agak padat pada peruratan pina epidermis adaksial manakala pada permukaan epidermis abaksial trikom ringkas multisel hadir tetapi sangat kurang padat. Hasil pemerhatian di bawah mikroskop cahaya menunjukkan trikom berlengan hadir pada bahagian stip A. angustifolia sementara trikom ringkas, multisel hadir pada bahagian stip $A$. evecta. Pada bahagian pina pula, kehadiran trikom peltat telah direkodkan pada epidermis abaksial pina $A$. evecta manakala pada $A$. angustifolia kehadiran trikom tidak direkodkan. 
Kehadiran hablur dan bintil kanji merupakan ciri tambahan yang membantu dalam taksonomi tumbuhan. Hasil kajian merekodkan bintil kanji hanya hadir pada tisu kolenkima adaksial bahagian stip $A$. evecta. Ringkasan bagi setiap ciri anatomi dan mikromorfologi pina untuk membezakan kedua-dua spesies ditunjukkan dalam Jadual 5 .

JADUAL 5. Ciri anatomi dan mikromorfologi pina yang membezakan A. angustifolia dan A. evecta

\begin{tabular}{|c|c|c|}
\hline $\begin{array}{l}\text { Ciri anatomi dan } \\
\text { mikromorfologi }\end{array}$ & A. angustifolia & A. evecta \\
\hline Corak peruratan pina & $\begin{array}{c}\text { Peruratan palsu hadir antara peruratan } \\
\text { pina } \\
\text { Peruratan tepi tidak menyentuh tepi } \\
\text { pina }\end{array}$ & $\begin{array}{l}\text { Peruratan palsu tidak hadir } \\
\text { Peruratan tepi menyentuh } \\
\text { tepi pina }\end{array}$ \\
\hline $\begin{array}{l}\text { Bentuk luaran stip permukaan } \\
\text { abaksial }\end{array}$ & Bentuk bulatan lebar & Bentuk $3 / 4$ bulatan \\
\hline Bentuk luaran tepi pina & Hujung tumpul & Hujung membulat \\
\hline Jenis stoma & Tetrasitik, staurositik & $\begin{array}{l}\text { Anisositik, tetrasitik, } \\
\text { staurositik }\end{array}$ \\
\hline Indeks kepadatan stoma & $13 \%$ & $15 \%$ \\
\hline $\begin{array}{l}\text { Anatomi corak dinding } \\
\text { antiklin pada sel epidermis } \\
\text { abaksial pina }\end{array}$ & Lurus, melengkung ke berombak & $\begin{array}{l}\text { Lurus, melengkung ke } \\
\text { berombak dan berombak ke } \\
\text { sinuat. }\end{array}$ \\
\hline $\begin{array}{l}\text { Mikromorfologi corak hiasan } \\
\text { kutikel epidermis adaksial } \\
\text { pada pina }\end{array}$ & $\begin{array}{c}\text { Dinding periklin tenggelam } \\
\text { membentuk lopak yang lebar, dinding } \\
\text { antiklin timbul membentuk rabung } \\
\text { nipis }\end{array}$ & $\begin{array}{l}\text { Dinding antiklin tenggelam, } \\
\text { dinding periklin timbul } \\
\text { membentuk bonjolan kubah }\end{array}$ \\
\hline $\begin{array}{l}\text { Mikromorfologi corak hiasan } \\
\text { kutikel epidermis abaksial } \\
\text { pada pina }\end{array}$ & $\begin{array}{c}\text { Dinding periklin tenggelam } \\
\text { membentuk lopak yang lebar dan } \\
\text { dinding antiklin timbul membentuk } \\
\text { rabung }\end{array}$ & $\begin{array}{l}\text { Dinding periklin timbul dan } \\
\text { dinding antiklin tenggelam }\end{array}$ \\
\hline $\begin{array}{l}\text { Mikromorfologi kehadiran } \\
\text { trikom }\end{array}$ & $\begin{array}{l}\text { Trikom berlengan- } 3 \text { hadir pada } \\
\text { peruratan pina abaksial sahaja }\end{array}$ & $\begin{array}{l}\text { Trikom berlengan-3 (dinding } \\
\text { beralur) hadir pada peruratan } \\
\text { pina, trikom ringkas multisel } \\
\text { hadir pada permukaan } \\
\text { epidermis abaksial }\end{array}$ \\
\hline Anatomi kehadiran trikom & $\begin{array}{c}\text { Trikom tidak hadir pada epidermis } \\
\text { abaksial pina, trikom berlengan hadir } \\
\text { pada stip }\end{array}$ & $\begin{array}{l}\text { Trikom peltat hadir pada } \\
\text { epidermis abaksial pina, } \\
\text { trikom ringkas, multisel hadir } \\
\text { pada stip }\end{array}$ \\
\hline $\begin{array}{l}\text { Kehadiran bintil kanji pada } \\
\text { stip }\end{array}$ & Tidak hadir & $\begin{array}{l}\text { Bintil kanji hadir pada tisu } \\
\text { kolenkima adaksial }\end{array}$ \\
\hline
\end{tabular}

\section{KEKUNCI DIKOTOMI PENGECAMAN SPESIES KAJIAN}

Berdasarkan gabungan ciri anatomi dan mikromorfologi di bawah cerapan mikroskop cahaya dan mikroskop imbasan elektron, kekunci dikotomi pengecaman spesies yang dikaji telah dibina.
Peruratan palsu pada pina fertil, peruratan tepi tidak menyentuh tepi pina, bentuk luaran stip permukaan abaksial berbentuk bulatan lebar, bentuk luaran tepi pina hujung tumpul. Hiasan kutikel epidermis adaksial dinding antiklin timbul dan dinding periklin tenggelam, epidermis abaksial dinding periklin tenggelam membentuk lopak; 
dinding antiklin timbul membentuk rabung, trikom berlengan-3 hadir pada peruratan pina abaksial. Stoma tetrasitik dan staurositik, indeks kepadatan stoma 13\%, corak dinding antiklin pada sel epidermis abaksial pina lurus dan melengkung ke berombak, trikom berlengan hadir pada stip, bintil kanji tidak hadir pada stip Angiopteris angustifolia.

Peruratan palsu tidak hadir pada pina fertil, peruratan tepi menyentuh tepi pina, bentuk luaran stip permukaan abaksial berbentuk $3 / 4$ bulatan, bentuk luaran tepi pina hujung membulat. Hiasan kutikel epidermis adaksial mempunyai dinding antiklin tenggelam dan dinding periklin timbul, epidermis abaksial mempunyai dinding periklin timbul dan dinding antiklin tenggelam, trikom berlengan-3 hadir pada peruratan pina adaksial, trikom ringkas multisel hadir pada permukaan epidermis abaksial. Stoma anisositik, tetrasitik, staurositik, indeks kepadatan stoma $15 \%$, corak dinding antiklin pada sel epidermis abaksial pina lurus, melengkung ke berombak dan berombak ke sinuat, trikom peltat hadir pada epidermis abaksial pina, trikom ringkas, multisel hadir pada stip, bintil kanji pada tisu kolenkima adaksial $A$. evecta.

\section{KESIMPULAN}

Kajian perbandingan ciri anatomi dan mikromorfologi pina $A$. angustifolia dan $A$. evecta di Semenanjung Malaysia ini merupakan kajian yang penting untuk membantu pengecaman dan pembezaan kedua-dua spesies kajian terutama sekali bagi spesimen steril dan tiada maklumat lapangan. Selain itu, kajian ini juga sangat jelas dapat memberi penambahan data maklumat ciri anatomi dan mikromorfologi daun dan juga amat berguna sebagai ciri tambahan untuk pengelasan bagi genus Angiopteris yang terdapat di Semenanjung Malaysia.

\section{PENGHARGAAN}

Penyelidikan ini telah dibiayai oleh geran penyelidikan FRGS/1/2019/STG03/UKM/02/3 dan GUP-2017-035.

\section{RUJUKAN}

Barthlott, W. 1990. Scanning electron microscopy of the epidermal surface in plants. Scanning Electron Microscopy in Taxonomy and Funtional Morphology 41: 69-94.

Barthlott, W., Nienhus, C., Cutler, D., Ditsch, F., Meusel, I. \& Wilhelmi, H. 1998. Classification and terminology of plant epicuticular waxes. Botanical Journal of Linnean Society 126: 237-260.

Bidin, A. 1985. Paku-pakis Ubatan di Semenanjung Malaysia. Kuala Lumpur: Dewan Bahasa dan Pustaka.

Bidin, A. 1984. The importance of leaf in the genus Adiantum L. Sains Malaysiana 13(3): 279-289.
Blomquist, H.L. 1922. Vascular anatomy of Angiopteris evecta. Botanical Gazette 73: 181-199.

Christenhusz, M.J.M., Fay, M.F. \& Chase, M.W. 2017. Plants of the World: An Illustrated Encyclopedia of Vascular Plants. Chicago: University of Chicago Press.

Christenhusz, M.J.M., Zhang, X.C. \& Schneider, H. 2011. A linear sequence of extant families and genera of lycophytes and ferns. Phytotaxa 19: 7-54.

de Winter, W.P. \& Amoroso, V.B. 2003. Plant Resources of South-East Asia 15(2) Cryptogams: Ferns and Fern Allies. Leiden: Backhuys Publishers.

He, Z.R. \& Christenhusz, M.J.M. 2013. Marattiaceae. http:// flora.huh.harvard.edu/china/mss/volume13/index.htm.

Hill, C.R. \& Camus, J.M. 1986. Evolutionary cladistics of marattialean ferns. Bulletin of the British Natural History Museum 14: 219-300.

Holttum, R.E. 1968. A Revised Flora of Malaya, Vol. II: Ferns of Malaya. American Fern Journal 60: 38-39.

Johansen, D.A. 1940. Plant Microtechnique. New York: McGrawHill Book Co.

Latiff, A. 2015. Cyathea arjae Latiff (Cyatheaceae). A new species of dwaft tree fern from Sayap, Mount Kinabalu, Sabah, Malaysia. Sains Malaysiana 44(1): 57-66.

Maideen, H., Arbawi, Y.A.M., Khaduwi, N.M. \& Kamil, N.N.N.M. 2018. A systematic study on the genus Cibotium Kaulf. of Peninsular Malaysia. Malaysian Applied Biology 47(3): 79-84.

Maideen, H., Hazwani, A.N., Nurfarahain, Z., Damanhuri, A., Noraini, T., Rusea, G., Qistina, L. \& Masnoryante, M. 2013. Systematic significance of stipe anatomy of Selaginella (Selaginellaceae) in Peninsular Malaysia. Sains Malaysiana 42 (5): 693-696.

Maideen, H., Jaman, R., Haji-Mohamed, A.M., Zulkapli, I. \& Latiff, A. 2002. The genus Marattia (Marattiaceae) in Malaysia. Malaysian Journal of Science 21: 31-35.

Metcalfe, C.R. \& Chalk, L. 1983. Anatomy of the Dicotyledons. Oxford: Clarendon Press.

Mohd Norfaizal, G., Noraini, T., Latiff, A., Mohd Shukri, M.A., Ahmad Zaki, Z. \& Nurshahidah, M.R. 2019. Morfologi debunga lima genus terpilih Sapindaceae di Semenanjung Malaysia. Sains Malaysiana 48(3): 487-496.

Murdock, A.G. 2008. A taxonomic revision of the eusporangiate fern family Marattiaceae, with description of a new genus Ptisana. Taxon 57(3): 737-755.

Mustarichie, R., Indriyati, W., Mukmin, A. \& Ramdhani, D. 2016. Activity of Angiopteris evecta for baldness treatment Journal of Chemical and Pharmaceutical Research 8(5): 821-830.

Noraini, T. \& Cutler, D.F. 2009. Leaf anatomical and micromorphological characters of some Malaysian Parashorea (Dipterocarpaceae). Journal of Tropical Forest Science 21(2): 156-167.

Noraini, T., Mohamad Ruzi, A.R. \& Muhammad Amirul Aiman, A.J. 2019. Anatomi dan Mikroskopik Tumbuhan. Bangi: Penerbit Universiti Kebangsaan Malaysia. 
Noraini, T., Amirul-Aiman, A.J., Jaman, R., Nor-Fairuz, A.R.N. \& Maideen, K.M. 2015. Systematic significance of stipe anatomy in Peninsular Malaysia Blechnum I. (Blechnaceae) species. Malaysian Applied Biology 43(2): 119-128.

Noraini, T., Ruzi, A.R., Nadiah, N., Nisa, R.N., Maideen, H. \& Solihani, S.N. 2012. Ciri anatomi stip bagi beberapa spesies Davallia (Davalliaceae) di Malaysia. Sains Malaysiana 41(1): 53-62.

Noraini, T., Ruzi, A.R., Razali, J. \& Latiff, A. 2008. Ferns and Fern-allies of Taman Paku Pakis Universiti Kebangsaan Malaysia. Bangi: Penerbit Universiti Kebangsaan Malaysia.

Ogura, Y. 1972. Comparative Anatomy of the Vegatative Organs of the Ptetidophytes. Berlin: Gebruder Borntraeger.

PPG I. 2016. A community-derived classification for extant lycophytes and ferns. Journal of Systematics and Evolution 54(6): 563-603.

Rolleri, C.H. 1993. Revision of the genus Christensenia. American Fern Journal 83(1): 3-19.

Rolleri, C., Deferrari, A. \& Lavalle, M.C. 1991. Epidermal morphology of the pinnae of Angiopteris, Danaea and Marattia. American Fern Journal 81(2): 44-62.

Rosalin, I. 2014. Keanekaragaman morfologi dan struktur reproduksi tumbuhan paku terestrial di Institut Pertanian Bogor-Darmaga. Institut Pertanian Bogor. M.Sc. Thesis (Tidak diterbitkan).

Sass, J.E. 1958. Botanical Microtechnique. Iowa: Iowa State University Press.

Sathiyaraj, G., Muthukumar, T. \& Ravindran, K.C. 2015. Ethnomedicinal importance of fern and fern allies traditionally used by tribal people of Palani Hills (Kodaikanal), Western Ghats, South India. Journal of Medicinal Herbs and Ethnomedicine 1(1): 4-9.

Sitorus, S. 2013. Uji sitotoksisitas ekstrak etanol Angiopteris angustifolia $\mathrm{C}$. Presl terhadap kultur sel kanker payudara (MCF-7 Cell Line) secara in-vitro. Universitas Islam Negeri, M.Sc. Thesis (Tidak diterbitkan).
Smith, A.R., Pryer, K.M., Schuettpelz, E., Korall, P. Schneider, H. \& Wolf, P.G. 2006. A classification for extant ferns. Taxon 55(3): 705-731.

Srivastava, K. 2008. Epidermal features and petiolar anatomy of Angiopteris evecta (Forst.) Hoffm. (Marattiaceae: Pteridophyta). Ethnobotanical Leaflets 12: 139-149.

van Konijnenburg-Van Cittert, J.H.A. 1975. Angiopteris blackii van Cittert nom. nov. Review of Palaeobotany and Palynology 20: 215.

Wagner, W.H. 1979. Reticulate veins in the systematics of modern ferns. Taxon 28: 87-95.

Noraini Talip*, Haja Maideen Kader Maideen \& Mohamad Ruzi Abdul Rahman

School of Biological Sciences \& Biotechnology

Faculty of Science \& Technology

Universiti Kebangsaan Malaysia

43600 UKM Bangi, Selangor Darul Ehsan

Malaysia

Siti Nor Azah Ayob

Jabatan Pertanian

Bahagian Biosekuriti Tumbuhan, Wisma Tani

Jalan Sultan Salahuddin

50632 Kuala Lumpur, Wilayah Persekutuan

Malaysia

Hamidun Bunawan

Institute of Systems Biology

Universiti Kebangsaan Malaysia

43600 UKM Bangi, Selangor Darul Ehsan

Malaysia

*Pengarang untuk surat-menyurat; email: ntalip@ukm.edu.my

Diserahkan: 29 Mei 2020

Diterima: 6 Oktober 2020 